\title{
Parent-child communication about sex and romantic feelings: does having older siblings make a difference?
}

\author{
Marta Pasqualini $i^{*}$ id and Alessandra De Rose ${ }^{2}$
}

\author{
* Correspondence: marta. \\ pasqualini@upf.edu \\ ${ }^{1}$ Department of Political and Social \\ Sciences, Universitat Pompeu Fabra, \\ C/ Ramon Trias Fargas, 25-27, 08005 \\ Barcelona, Spain \\ Full list of author information is \\ available at the end of the article
}

\begin{abstract}
Parental involvement in sex education and the quality of parent-child communication about romantic feelings appear to have a protective effect on adolescent sexual behaviours. However, little research has been conducted on the role played by birth order in the level of parental involvement in sex education. This is the first study seeking to address if the quality of parent-child communication about sex and romantic sentiments differs according to whether respondents have_-or do not have_older siblings in Italy. Hypotheses concerning the role of sibship gender composition have been tested in order to explain potential intervening mechanisms. Data were drawn from the Sexual and Emotional Life of Youths survey (SELFY), a cross-sectional survey conducted in 2000 and in 2017 on Italian university students $(N=12,265)$. Our findings identify later-born children as the least likely to confide in parents. Although boys are generally less likely to talk to parents than girls, respondent gender does not moderate the effect of birth order. Instead, sibship gender composition plays a role: having grown up with at least one samegender sibling is associated with a lower communication with parents about intimate matters. This study suggests that growing up with siblings, namely with same-gender siblings, make a difference in parent-child communication and this should be considered while evaluating the role of parental involvement in adolescent sexual education.
\end{abstract}

\section{Background and hypotheses}

The family of origin, as the primary place of socialization, has a strong influence on young people's sexual behaviour and emotional life (Furstenberg Jr., Moore, \& Peterson, 1985; Miller, 1998; Morris, Silk, Steinberg, Myers, \& Robinson, 2007) and parents, more than other household members, are powerful sources of influence in shaping the health-related conduct of adolescents (Eisenberg, Sieving, Bearinger, Swain, \& Resnick, 2006).

The involvement of parents in topics related to sex and romantic feelings is a critical factor in the prevention of risky sexual behaviours of children, which often compromises their sexual health (Cheshire, Kaestle, \& Miyazaki, 2019; Olusanya, 2018). Thus, parent-child communication is considered a powerful instrument for promoting health

(c) The Author(s). 2020 Open Access This article is licensed under a Creative Commons Attribution 4.0 International License, which permits use, sharing, adaptation, distribution and reproduction in any medium or format, as long as you give appropriate credit to the original author(s) and the source, provide a link to the Creative Commons licence, and indicate if changes were made. The images or other third party material in this article are included in the article's Creative Commons licence, unless indicated otherwise in a credit line to the material. If material is not included in the article's Creative Commons licence and your intended use is not permitted by statutory regulation or exceeds the permitted use, you will need to obtain permission directly from the copyright holder. To view a copy of this licence, visit http://creativecommons.org/licenses/by/4.0/. 
prevention programmes addressed at adolescents (Widman, Choukas-Bradley, Noar, Nesi, \& Garrett, 2016). Reporting a parent as a main source of sex education has been associated with later ages at first sexual intercourse and with more frequent use of contraceptives (Crosby, Hanson, \& Rager, 2009; D'Cruz et al., 2015; Elton, Palmer, \& Macdowall, 2018; MacDowall et al., 2015). Parental monitoring and supervision were also consistently associated with a safe and healthy sexual debut (Chewning \& Van Koningsveld, 1998; Feldman \& Brown, 1993; Hogan \& Kitagawa, 1985; Hutchinson, Jemmott, Jemmott, Braverman, \& Fong, 2003; Rodgers, Rowe, \& Harris, 1992; Rogers, Ha, Stormshak, \& Dishion, 2015; Small \& Luster, 1994). Indeed, by expressing their own values and beliefs regarding risks, parents play a critical role in conveying sexual information as part of their communication (Eisenberg et al., 2006; Widman et al., 2016). In addition, by providing open and honest communication about sexual health issues, parents offer a powerful model to be emulated by their children in their own eventual sexual relationships (Widman et al., 2016).

Several studies, mainly conducted in the United Kingdom (UK) and the United States (USA), have reported that the level and quality of parent-child communication about sexual affairs vary according to gender. For example, British girls are found to be three times as likely as boys in reporting a parent as their main source of sex education (Macdowall et al., 2006; Macdowall et al., 2015). A large body of theoretical and empirical studies demonstrated that mothers are more likely to talk with their children about sex topics than fathers are, and more frequently with daughters than with sons, while fathers prefer talking with sons (see reviews on the topic by Di Iorio, Pluhar, \& Belcher, 2003, and Racz \& McMahon, 2011). Also, the style of communication is different between mothers and fathers in talking to daughters or to sons (Byers, Sears, \& Weaver, 2008; Nolin \& Peterson, 1992; Whalen, Henker, Hollingshead, \& Burgess, 1996). Among American college students, Darling and Hicks (1982) identified a double standard in parental discourse about sexuality: when talking with a son, parents tend to emphasize the positive side of sexual experience, while with girls they often underline the risks of sexual intercourse and moral disapproval. The effect of parental communication on children's effective behaviour changes according to whether the parent speaks to a son or a daughter. For example, Moore, Peterson, and Furstenberg (1986) found that the probability of a daughter to have early sexual intercourse is reduced if she talked with parents on the topic, while it increases for a boy. Wilson and Koo (2010) found that mothers are generally more likely to talk to both their sons and their daughters about sex than fathers, and that mothers talk much more to their daughters than their sons. More surprisingly, they found that fathers were not more likely to talk to sons than daughters about any topic and that fathers were more likely to talk to daughters than sons about one topic: dating and relationships. Similar mixed findings have been registered in relation to adolescent contraceptive behaviours, while a positive effect of parent-child communication on avoiding risks of sexually transmitted infections (STIs) has been found for both daughters and sons. Overall, studies confirm that gender is an important factor that may influence parent-child communication about sexual topics and its effects (Di Iorio et al., 2003).

Another source of variability as far as parent-child communication is concerned is the presence of siblings in the same household and the child's birth order. According to a recent study conducted in the UK (Elton et al., 2018), first-born 
children are significantly more likely to report parents as a source of sex education than later-born children. The varying psycho-social environment experienced by children of different birth order has been used as a possible explanation of these findings (Elton et al., 2018). For example, while first-born children have been described as being under pressure to conform to adults' expectations and displaying behaviours that mirror their parents' will, such as high self-responsibility (Baskett, 1985), later-born children have been shown to behave in the opposite way (Sulloway, 1996, 2007). First-born children have been described as more likely to report high levels of parental control and influence (Ng, Mofrad, \& Uba, 2014), with parental discipline weakening from first-born to last-born (Hotz \& Pantano, 2015). Moreover, parents tend to engage in different parenting strategies with children of different birth order (Hotz \& Pantano, 2015) and siblings receiving more parental attention are expected to have more positive emotions towards the family compared with siblings receiving less parental attention (Bu \& Sulloway, 2016; Hertwig, Davis, \& Sulloway, 2002). For the UK, Booth and Kee (2009) found that in the presence of more than one child, parents do not assign equal shares in the family's educational resources and that the amount of resources devoted to each child decreases with birth order. Similar findings have been found for Italy, France (Ferrari \& Dalla Zuanna, 2010), and Germany (Harkonen, 2012). Overall, the amount and quality of parent-child communication are influenced by the number of siblings. Indeed, the interaction between parents and children may be less intensive as the number of children increases since parental supervision and discipline may be harder to achieve with a greater number of children (Elton et al., 2018).

The presence of brothers and sisters within the same household plays an important role in moderating the level and quality of communication between a child and his/her parents. Interaction between siblings is an important mechanism by which adolescents socialize one another's romantic relationship involvement and sexuality development. Having had a deep talk with siblings about sexual affairs is associated with a lower likelihood of having had an open conversation with parents on the same topic (Kowal \& Blinn-Pike, 2004).

It is not just the presence and the number of siblings that must be considered as key agents in family dynamics, but also the gender constellation, with same-gender (older) siblings being more influential than opposite-gender siblings (McHale, Updegraff, \& Whiteman, 2012; Widmer, 1997). The level of intimacy and the relational balance of power within sibling dyads is strongly dependent on their gender composition and since same-gender siblings are more likely to report access to shared life events than opposite-gender siblings, this contributes to increase their level of closeness. Having an older, same-gender sibling has been linked with a high probability of confiding in him/her and to use the sibling as a socializing agent of sexuality (Killoren \& Roach, 2014; McHale et al., 2012; Rodgers \& Rowe, 1988). Moreover, some research has argued that what has been considered a "same-gender effect" is better described as a "sister-effect" suggesting that a sisters' dyad may be particularly important in the socialization of adolescent sexuality due to their greater levels of intimacy (Widmer, 1997).

In this paper, we address the topic of parent-child communication about sex and romantic feelings in Italy, exploring differences by birth order. We will also question if 
and how parent-child communication changes according to gender composition of the offspring.

The specific aims of this paper are:

1. To investigate whether parental involvement in sex education and the quality of parent-child communication about romantic feelings differ according to the respondent's birth order. We expect a lower involvement with later-born children than with first-born or only children (HP1).

2. To verify whether the above relationship is differentiated by gender: we expect that differences between being an only child or first-born and later-born are higher for male respondents (HP2).

3. To explore whether sib-ship gender composition contributes to explaining this difference. More specifically, the following hypotheses have been formulated:

- (HP3_1) Since a same-gender sibling may serve as a referent-person in confiding romantic feelings and sexual experiences, we hypothesize that individuals having only same-gender siblings or at least one same-gender older sibling are less likely to report of having had a deep communication with parents about sex and sentiments than those having only opposite-gender siblings.

- (HP3_2) Since dyads of sisters are more likely to provide socialization of adolescent sexuality, this effect is expected to be higher if the respondent is a girl (the "sister effect").

This is the first study looking at the association between birth order and parent-child communication about sex and romantic feelings in Italy. Exploring the determinants of parental involvement in sex education may contribute to target effective preventive programmes aimed at promoting healthy sexual debut and behaviours over the life span (Miller \& Whitaker, 2001). Indeed, with the aim of addressing the simultaneous role of family members as confidants about sexuality, this paper seeks to elucidate underestimated aspects of intimate communication between parents and children, related to birth order and sib-ship gender composition.

\section{Data and method}

\section{Data and analytic strategy}

Data are drawn from the Sexual and Emotional Life of Youths surveys (SELFY) that were carried out in 2000 and 2017 in 28 Italian universities, with the aim of drawing an updated picture of sexual and emotional opinions and behaviours among Italian university students attending Italian undergraduate courses in Economics and Statistics (Dalla Zuanna, Caltabiano, Minello, \& Vignoli, 2019). About 5000 students in 2000 and 8000 in 2017 were surveyed using a self-completed questionnaire filled out in the classroom during a lecture. After the exclusion of incomplete and poorly filled out questionnaires, the sample survey consists of 12,604 cases (4762 individuals interviewed in 2000 and 7842 in 2017). Survey focus is on the emotional life of respondents, asking questions on first intercourse 
determinants and on intercourse and sentimental relationship event history, along with personal, social, and family information. For both 2000 and 2017, the data were post-stratified at the macro-region level to obtain representative results at the national level. The analytic sample used in the current study comprises 12,265 students ( $48.19 \%$ men) on the basis of complete cases of the main variable of interest ( $3 \%$ of non-response).

After a sample descriptive analysis (Table 1), four multivariate logistic regression models with and without interaction terms have been estimated in order to investigate whether having or not having older siblings and the sib-ship gender composition is associated to parentchild communication about (1) sex development, (2) STIs, (3) contraceptives, and (4) romantic feelings. We performed a two-step analysis. First, we tested the effect of birth order on the probability of having had a deep conversation with parents (HP1) and the moderating effect of gender (HP2). Full model coefficients estimates are reported in Table 2. Then, we concentrated on the sub-sample of respondents who are "later-born" children, that is, those with at least one older sibling $(N=6,261)$, and we deepened the analysis of the association between the different sib-ship gender composition (HP3_1) and parent-child communication, controlling again for the moderating effect of gender (HP3_2). The results are reported in Table 3. Predicted probabilities have been estimated from logistic regressions and have been reported in Figs. 1, 2, 3. Details on the variables included in the models are provided in the following section.

\section{Variables}

\section{Dependent variables}

Parental involvement in sex and sentimental education was assessed by identifying four outcome variables. Respondents were asked whether they had ever spoken with parents during their adolescence (14 to 18 years old) about (1) sexual development, (2) STIs, (3) contraceptive methods, and (4) romantic feelings.

The survey coded possible answers as follows: "never", "in a superficial way", and "in a deep way". In order to capture a profound level of parental involvement in sex education, we created a dummy variable which takes value 1 if they reported having spoken with their parents in a deep way and 0 otherwise. Unfortunately, information about parent-child communication is not distinguished between mother and father. Thus, we cannot account for parental gender.

\section{Independent variables}

The key explanatory variable is birth order. The questionnaire does not exactly provide the birth order of all the children present in the family. We know the respondent's date of birth and that of the first child born to the parents. In addition, the respondent is asked if he/she has older brothers or sisters. The variable was therefore dichotomized as first-born/only child versus later-born child.

Sib-ship gender composition: Among later-born respondents, we can distinguish the gender composition of the siblings-ship; thus, we included a variable accounting for whether the respondent was a later-born of same-gender siblings, of opposite-gender or of mixed-gender siblings.

Parent-child communication is correlated to a number of factors that we controlled for in all the models. Specifically, we included the respondent's gender, age at the interview (18 to 
Table 1 Distribution of the sample variables by birth order

\begin{tabular}{|c|c|c|c|c|}
\hline \multirow[t]{2}{*}{ Variables } & Total & $\begin{array}{l}\text { First born- } \\
\text { Only child }\end{array}$ & Later born & p-value \\
\hline & $\mathrm{N}=12,265$ & $\mathrm{~N}=6,004$ & $\mathrm{~N}=6,261$ & \\
\hline Dependent & \multicolumn{4}{|c|}{$\%$} \\
\hline \multicolumn{5}{|c|}{$\begin{array}{l}\text { Having had a deep communication with parents (at least one of } \\
\text { them) between ages 14-18 about: }\end{array}$} \\
\hline Sexual Development & 20.78 & 24.17 & 17.43 & $<0.001$ \\
\hline Sexually Transmitted Infections (STIs) & 19.72 & 22.17 & 17.15 & $<0.001$ \\
\hline Contraceptive methods & 19.98 & 23.35 & 16.63 & $<0.001$ \\
\hline Romantic Feelings & 23.32 & 26.07 & 20.67 & $<0.001$ \\
\hline Independent & \multicolumn{4}{|c|}{$\% ;$ Mean (SD) } \\
\hline \multicolumn{5}{|l|}{ Sib-ship gender composition } \\
\hline Later born of same-gender siblings & & & 44.63 & \\
\hline Later born of opposite-gender siblings & & & 43.06 & \\
\hline Later born of mixed-gender siblings & & & 12.31 & \\
\hline \multicolumn{5}{|l|}{ Gender: Woman } \\
\hline Man & 48.19 & 49.67 & 46.72 & $<0.01$ \\
\hline Age at the interview & $21.07(1.47)$ & $21.06(1.45)$ & $21.08(1.48)$ & $>0.1$ \\
\hline \multicolumn{5}{|l|}{ Country of birth: Italy } \\
\hline Other & 4.10 & 4.20 & 3.99 & $>0.1$ \\
\hline Living in Southern Italy & 40.73 & 35.44 & 45.66 & $<0.001$ \\
\hline Lower secondary school's grade & $8.35(1.22)$ & $8.41(1.21)$ & $8.29(1.22)$ & $<0.001$ \\
\hline \multicolumn{5}{|c|}{ Participation in religious groups (respondent $11-13$ years old) } \\
\hline Never & 53.44 & 55.02 & 51.93 & $<0.01$ \\
\hline Some times & 18.04 & 17.62 & 18.46 & \\
\hline Often & 15.88 & 15.66 & 16.06 & \\
\hline Very often & 12.64 & 11.70 & 13.56 & \\
\hline \multicolumn{5}{|c|}{ Talk with friends about sex (respondent 11-13 years old) } \\
\hline Never & 53.59 & 53.48 & 53.76 & $>0.1$ \\
\hline Some times & 37.66 & 37.94 & 37.40 & \\
\hline Often & 6.64 & 6.43 & 6.84 & \\
\hline Very often & 2.11 & 2.15 & 1.99 & \\
\hline \multicolumn{5}{|l|}{ Family structure } \\
\hline Parents divorced before respondent's age of 13 & 5.58 & 6.60 & 4.59 & $<0.001$ \\
\hline \multicolumn{5}{|l|}{ Mother educational level } \\
\hline up to lower-secondary level & 31.23 & 28.27 & 34.14 & $<0.001$ \\
\hline upper-secondary level & 49.33 & 51.07 & 47.69 & \\
\hline university or higher level & 19.44 & 20.66 & 18.17 & \\
\hline \multicolumn{5}{|l|}{ Father educational level } \\
\hline up to lower-secondary level & 33.34 & 32.08 & 34.66 & $<0.001$ \\
\hline upper-secondary level & 46.40 & 48.13 & 44.69 & \\
\hline university or higher level & 20.26 & 19.79 & 20.65 & \\
\hline \multicolumn{5}{|l|}{ Father's job } \\
\hline never worked & 0.88 & 0.98 & 0.77 & $<0.001$ \\
\hline low-skilled & 36.02 & 36.66 & 35.46 & \\
\hline medium-skilled & 32.29 & 33.03 & 31.58 & \\
\hline high-skilled & 30.81 & 29.34 & 32.19 & \\
\hline \multicolumn{5}{|c|}{ Mother employment status (respondent 11-13 years old) } \\
\hline Yes, employed & 33.15 & 29.99 & 36.15 & $<0.001$ \\
\hline Distance in years from first born & $1.90(3.92)$ & $0(0)$ & $3.74(4.80)$ & \\
\hline Mother's age at time of respondent's birth & & & & \\
\hline$<25$ & 14.40 & 22.68 & 6.45 & $<0.001$ \\
\hline $25-30$ & 38.81 & 44.90 & 32.89 & \\
\hline $30-35$ & 19.40 & 15.36 & 23.39 & \\
\hline $35-40$ & 17.38 & 9.43 & 25.11 & \\
\hline $40+$ & 10.02 & 7.63 & 12.27 & \\
\hline Father's age at time of respondent's birth & & & & \\
\hline$<25$ & 3.59 & 6.08 & 1.23 & $<0.001$ \\
\hline $25-30$ & 27.17 & 38.64 & 16.08 & \\
\hline $30-35$ & 22.43 & 22.95 & 21.98 & \\
\hline $35-40$ & 28.11 & 19.99 & 35.98 & \\
\hline $40+$ & 18.70 & 12.34 & 24.72 & \\
\hline Way to react to parental rules (respondent 16- & & & & \\
\hline Accepting without discussing & 19.87 & 20.05 & 19.75 & 0.05 \\
\hline Seeking to negotiate more freedom & 62.13 & 61.16 & 62.93 & \\
\hline Quarrelling & 17.99 & 18.79 & 17.32 & \\
\hline Survey & & & & \\
\hline 2017 & 62.18 & & & \\
\hline
\end{tabular}

Source: SELFY (2000 and 2017)

Note: $p$ value refers to the $X^{2}$ test for categorical variables and to two-sample $t$ test for continuous variables. SD standard deviation 
Table 2 Estimated coefficients of logistic regression models for the probability to have a deep communication with parents on sexual and romantic topics - ALL students

\begin{tabular}{|c|c|c|c|c|c|c|c|c|}
\hline \multirow[t]{2}{*}{ Variables } & \multicolumn{2}{|c|}{$\begin{array}{c}1) \\
\text { Sexual Development }\end{array}$} & \multicolumn{2}{|c|}{$\begin{array}{l}(2) \\
\text { STIs }\end{array}$} & \multicolumn{2}{|c|}{$\begin{array}{c}\text { (3) } \\
\text { Contraceptive methods }\end{array}$} & \multicolumn{2}{|c|}{$\begin{array}{c}\text { (4) } \\
\text { Romantic Feelings }\end{array}$} \\
\hline & B & SE & B & $\mathrm{SE}$ & B & $\mathrm{SE}$ & B & $\mathrm{SE}$ \\
\hline Later born (ref. first born/only child) & $-0.294 * * *$ & $(0.070)$ & $-0.160^{* * *}$ & $(0.076)$ & $-0.270^{* * *}$ & $(0.075)$ & $-0.299 * * *$ & $(0.067)$ \\
\hline Man (ref. woman) & $-0.750 * * *$ & $(0.070)$ & -0.078 & $(0.070)$ & $-0.288 * * *$ & $(0.070)$ & $-0.920 * * *$ & $(0.070)$ \\
\hline Later born X Man (interaction) & 0.006 & $(0.103)$ & 0.002 & $(0.101)$ & 0.078 & $(0.101)$ & 0.157 & $(0.099)$ \\
\hline \begin{tabular}{|l|l|} 
Age at the interview \\
\end{tabular} & $-0.039 * *$ & $(0.017)$ & -0.011 & $(0.017)$ & -0.029 & $(0.018)$ & $-0.076^{* * *}$ & $(0.017)$ \\
\hline Country of birth: other (ref. Italy) & -0.233 & $(0.142)$ & -0.018 & $(0.138)$ & -0.185 & $(0.138)$ & -0.138 & $(0.135)$ \\
\hline Living in Southern Italy (ref, no) & $-0.388 * * *$ & $(0.054)$ & $-0.188^{* * *}$ & $(0.054)$ & $-0.424 * * *$ & $(0.055)$ & 0.054 & $(0.051)$ \\
\hline Lower secondary school's grade & 0.023 & $(0.021)$ & $-0.0576 * * *$ & $(0.021)$ & $-0.060^{* * *}$ & $(0.021)$ & -0.018 & $(0.020)$ \\
\hline Participation in religious groups: Some-times (ref. never) & -0.093 & $(0.069)$ & $-0.131 *$ & $(0.070)$ & -0.093 & $(0.069)$ & 0.024 & $(0.065)$ \\
\hline Often (ref. never) & $0.149 * *$ & $(0.069)$ & $0.116^{*}$ & $(0.070)$ & 0.015 & $(0.070)$ & $0.143 * *$ & $(0.067)$ \\
\hline Very-often (ref. never) & 0.097 & $(0.076)$ & -0.026 & $(0.079)$ & $-0.147^{*}$ & $(0.081)$ & $0.205 * * *$ & $(0.072)$ \\
\hline Talk with friends about sex: Some-times (ref. never) & $0.257 * * *$ & $(0.053)$ & $0.192 * * *$ & $(0.054)$ & $0.189 * * *$ & $(0.054)$ & $0.104 * *$ & $(0.052)$ \\
\hline Often (ref. never) & $0.289 * * *$ & $(0.107)$ & $0.182^{*}$ & $(0.105)$ & $0.191 *$ & $(0.106)$ & $0.267 * * *$ & $(0.102)$ \\
\hline Very- often (ref, never) & $0.331^{*}$ & $(0.193)$ & 0.235 & $(0.186)$ & 0.016 & $(0.198)$ & 0.060 & $(0.196)$ \\
\hline Mother educational level: upper-secondary (ref. up to lower- & & & & & & & & \\
\hline secondary) & $0.250^{* * *}$ & $(0.065)$ & $0.349 * * *$ & $(0.067)$ & $0.313^{* * *}$ & $(0.067)$ & $0.157^{* *}$ & $(0.061)$ \\
\hline university or higher level (ref. up to lower-secondary) & $0.161^{*}$ & $(0.092)$ & $0.435 * * *$ & $(0.092)$ & $0.284 * * *$ & $(0.092)$ & 0.007 & $(0.089)$ \\
\hline Father educational level: upper-secondary (ref. up to lower- & & & & & & & & \\
\hline secondary) & 0.090 & $(0.064)$ & 0.094 & $(0.065)$ & 0.091 & $(0.065)$ & 0.094 & $(0.060)$ \\
\hline university or higher level (ref. up to lower-secondary) & $0.191 * *$ & $(0.090)$ & 0.101 & $(0.091)$ & 0.111 & $(0.091)$ & 0.089 & $(0.088)$ \\
\hline Father's job: medium-skilled (ref. low-skilled) & 0.095 & $(0.063)$ & 0.099 & $(0.064)$ & 0.016 & $(0.064)$ & 0.062 & $(0.060)$ \\
\hline high-skilled (ref. & $0.242^{* * *}$ & $(0.070)$ & $0.280^{* * *}$ & $(0.071)$ & $0.218^{* * *}$ & $(0.070)$ & $0.211^{* * *}$ & $(0.067)$ \\
\hline Mother employment status ( $\mathrm{ref}$. no) & -0.009 & $(0.056)$ & 0.059 & $(0.057)$ & $-0.101^{*}$ & $(0.058)$ & 0.006 & $(0.053)$ \\
\hline Distance in year from first-born & $-0.137 *$ & $(0.082)$ & -0.135 & $(0.083)$ & -0.122 & $(0.083)$ & 0.094 & $(0.076)$ \\
\hline Mother's age at time of respondent's birth: $<25$ (ref. $25-30)$ & & & & & & & & \\
\hline & 0.047 & $(0.081)$ & 0.085 & $(0.081)$ & 0.112 & $(0.083)$ & 0.047 & $(0.078)$ \\
\hline $30-35$ (ref. 25-30) & -0.068 & $(0.074)$ & $-0.149 *$ & $(0.076)$ & -0.073 & $(0.074)$ & $-0.150 * *$ & $(0.071)$ \\
\hline $35-40$ (ref. 25-30) & -0.104 & $(0.089)$ & -0.098 & $(0.090)$ & $-0.184 * *$ & $(0.090)$ & $-0.176 * *$ & $(0.085)$ \\
\hline $40+($ ref. $25-30)$ & $-0.342^{* * *}$ & $(0.132)$ & $-0.245^{*}$ & $(0.131)$ & $-0.329 * *$ & $(0.132)$ & $-0.361 * * *$ & $(0.126)$ \\
\hline Father's age at time of respondent's birth: $<25($ ref. $25-30)$ & 0.207 & $(0.135)$ & $0.242^{*}$ & $(0.135)$ & $0.371^{* * *}$ & $(0.134)$ & $0.356^{* * *}$ & $(0.128)$ \\
\hline $30-35$ (ref. 25-30) & -0.105 & $(0.073)$ & -0.049 & $(0.073)$ & -0.068 & $(0.074)$ & -0.061 & $(0.070)$ \\
\hline $35-40$ (ref. 25-30) & -0.068 & $(0.080)$ & -0.119 & $(0.082)$ & -0.066 & $(0.081)$ & -0.117 & $(0.077)$ \\
\hline $40+($ ref. 25-30) & -0.105 & $(0.110)$ & -0.154 & $(0.112)$ & -0.109 & $(0.111)$ & $-0.226 * *$ & $(0.106)$ \\
\hline Family structure: Divorced before respondent's age of 13 & & & & & & & & \\
\hline (ref. no) & $0.436 * * *$ & $(0.101)$ & $0.231 * *$ & $(0.105)$ & $0.424 * * *$ & $(0.097)$ & $0.305 * * *$ & $(0.101)$ \\
\hline Way to react to parental rules: Accepting without discussing & & & & & & & & \\
\hline (ref. seeking to negotiate more freedom) & 0.095 & $(0.063)$ & $0.167 * * *$ & $(0.063)$ & 0.067 & $(0.064)$ & 0.062 & $(0.061)$ \\
\hline Quarrelling (ref, seeking to negotiate $n$ & $-0.480^{* * *}$ & $(0.072)$ & $-0.373 * * *$ & $(0.072)$ & $-0.271^{* * *}$ & $(0.071)$ & $-0.389 * * *$ & $(0.068)$ \\
\hline Survey: 2017 (ref. 2000) & $-0.095^{*}$ & $(0.055)$ & $-0.261 * * *$ & $(0.055)$ & $0.249^{* * *}$ & $(0.057)$ & $0.163^{* * *}$ & $(0.053)$ \\
\hline Goodness of fit & LR chi2 & $536.32 * * *$ & LR chi2 & $294.98 * * *$ & LR chi2 & $366.98 * * *$ & LR chi2 & $501.62 * * *$ \\
\hline
\end{tabular}

Source: SELFY (2000 and 2017)

Note: $N=12,160$. Log-odds (B) and standard error (SE) ${ }^{*} p<0.1,{ }^{* *} p<0.05,{ }^{* * *} p<0.01$. Respondents reporting "neverwork" fathers have been excluded from the analyses

26 years old), country of birth ("Italy" versus "other") and the macro-region of residence (we included a dummy variable taking value 1 if the respondent lives in Southern Italy and 0 otherwise). As a measure of educational achievement, we included the grade obtained at the end of lower-secondary school. Also, religiosity and church attendance are related to teenagers' attitude towards sexual affairs (Caltabiano, 2006; Caltabiano, Dalla Zuanna, \& Rosina, 2006) and their willingness to talk about it with parents (Regnerus, 2005). Therefore, we controlled for whether respondents participated in religious groups when they were 11 to 13 years old ("excluding catechism, have you ever participated in religious groups?"). During adolescence, talking about sex and intimate relationships with peers may highly mitigate or even substitute for that with parents (Dishion, Piehler, \& Myers, 2008; Potard, Courtois, \& Rusch, 2008). Thus, we controlled for whether respondents were accustomed to talking with peers about sexual issues between the ages of 11 and 13: "With your friends, were you

Table 3 Estimated coefficients of logistic regression models for the probability to have a deep communication with parents on sexual and romantic topics-later-born students

\begin{tabular}{|c|c|c|c|c|c|c|c|c|}
\hline \multirow[t]{2}{*}{ Variables } & \multicolumn{2}{|c|}{$\begin{array}{c}(1) \\
\text { Sexual Development }\end{array}$} & \multicolumn{2}{|c|}{$\begin{array}{ll}(2) \\
\text { STIs }\end{array}$} & \multicolumn{2}{|c|}{$\begin{array}{c}\text { (3) } \\
\text { Contraceptive methods }\end{array}$} & \multicolumn{2}{|c|}{$\begin{array}{c}\text { (4) } \\
\text { Romantic Feelings }\end{array}$} \\
\hline & $\mathrm{B}$ & SE & B & SE & B & SE & $\mathrm{B}$ & SE \\
\hline $\begin{array}{l}\text { Later born of same - gender siblings (ref. later born of } \\
\text { opposite-gender siblings) }\end{array}$ & -0.143 & $(0.097)$ & -0.115 & $(0.108)$ & $-0.176^{*}$ & $(0.107)$ & -0.092 & $(0.091)$ \\
\hline $\begin{array}{l}\text { Later born of mixed-gender siblings (ref. Later born of } \\
\text { opposite-gender siblings) }\end{array}$ & $-0.465 * * *$ & $(0.171)$ & -0.204 & $(0.179)$ & $-0.504 * * *$ & $(0.192)$ & $-0.367^{* *}$ & $(0.151)$ \\
\hline Man (ref. woman) & $-0.893 * * *$ & $(0.118)$ & -0.131 & $(0.113)$ & $-0.272 * * *$ & $(0.113)$ & $-0.845^{* * *}$ & $(0.110)$ \\
\hline Later born of same - gender siblings $\mathbf{X}$ Man (interaction) & 0.207 & $(0.163)$ & 0.125 & $(0.157)$ & 0.064 & $(0.159)$ & 0.158 & $(0.152)$ \\
\hline Later born of mixed-gender siblings X Man (interaction) & 0.450 & $(0.274)$ & -0.053 & $(0.266)$ & 0.355 & $(0.273)$ & 0.035 & $(0.259)$ \\
\hline Goodness of fit & LR chi2 & $220.39 * * *$ & LR chi2 & $150.15 * * *$ & LR chi2 & $178.14 * * *$ & LR chi2 & $197.35 * * *$ \\
\hline
\end{tabular}

Source: SELFY (2000 and 2017)

Note: $N=6213$. Log-odds (B) and standard error (SE). ${ }^{*} p<0.1,{ }^{* *} p<0.05,{ }^{* * *} p<0.01$. The estimates are fully adjusted for the covariates as reported in Table 1. Respondents reporting "never-work" fathers have been excluded from the analyses 


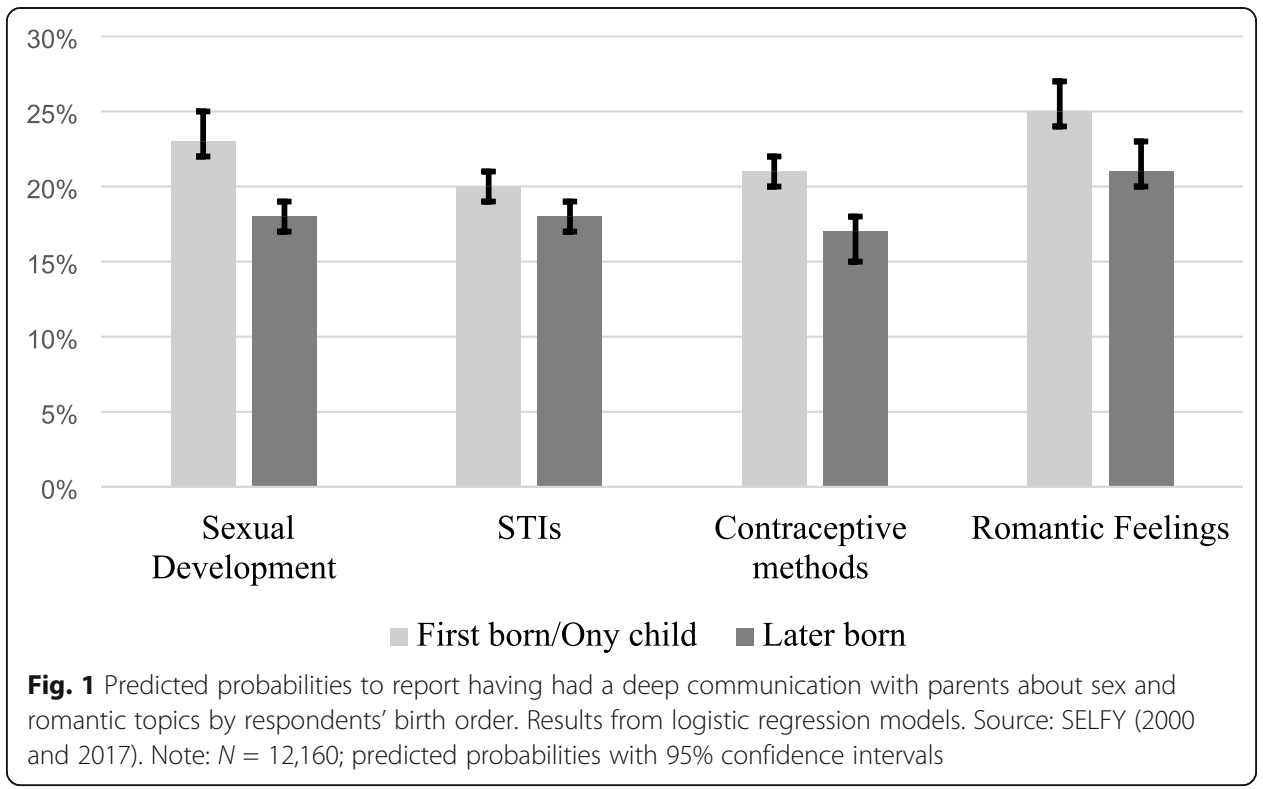

explicitly talking about sex?". Possible answers were "never", "sometimes", "often", and "very often".

The characteristics of the family of origin were measured through a set of variables referring to when the child was 13 years old. First of all, we considered whether parents were divorced or not. Indeed, union dissolution is often associated with the risky behaviours of children, since it implies reduced parental control and lower mentoring of children's socialization to sexuality (McLanahan \& Bumpass, 1988). As for indicators of the household socio-economic status, we included the mother's and father's educational levels and the father's job. The educational level was categorized as: "up to lower-secondary level" (no title, elementary school, lower-secondary school); "upper-secondary level" (upper-secondary courses lasting from $2 / 3$ to 5 years), and "university or higher level" (university and postuniversity degree). The father's job includes the following categories: "never worked", "low-

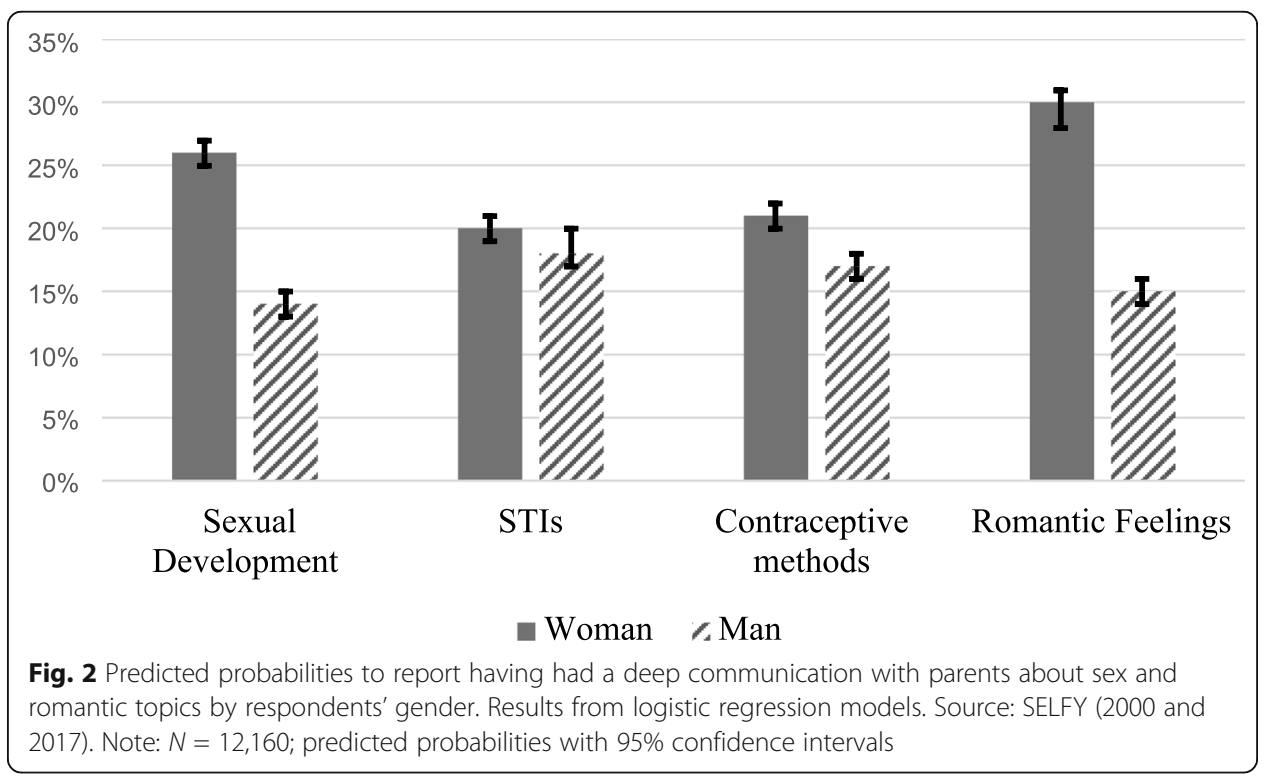




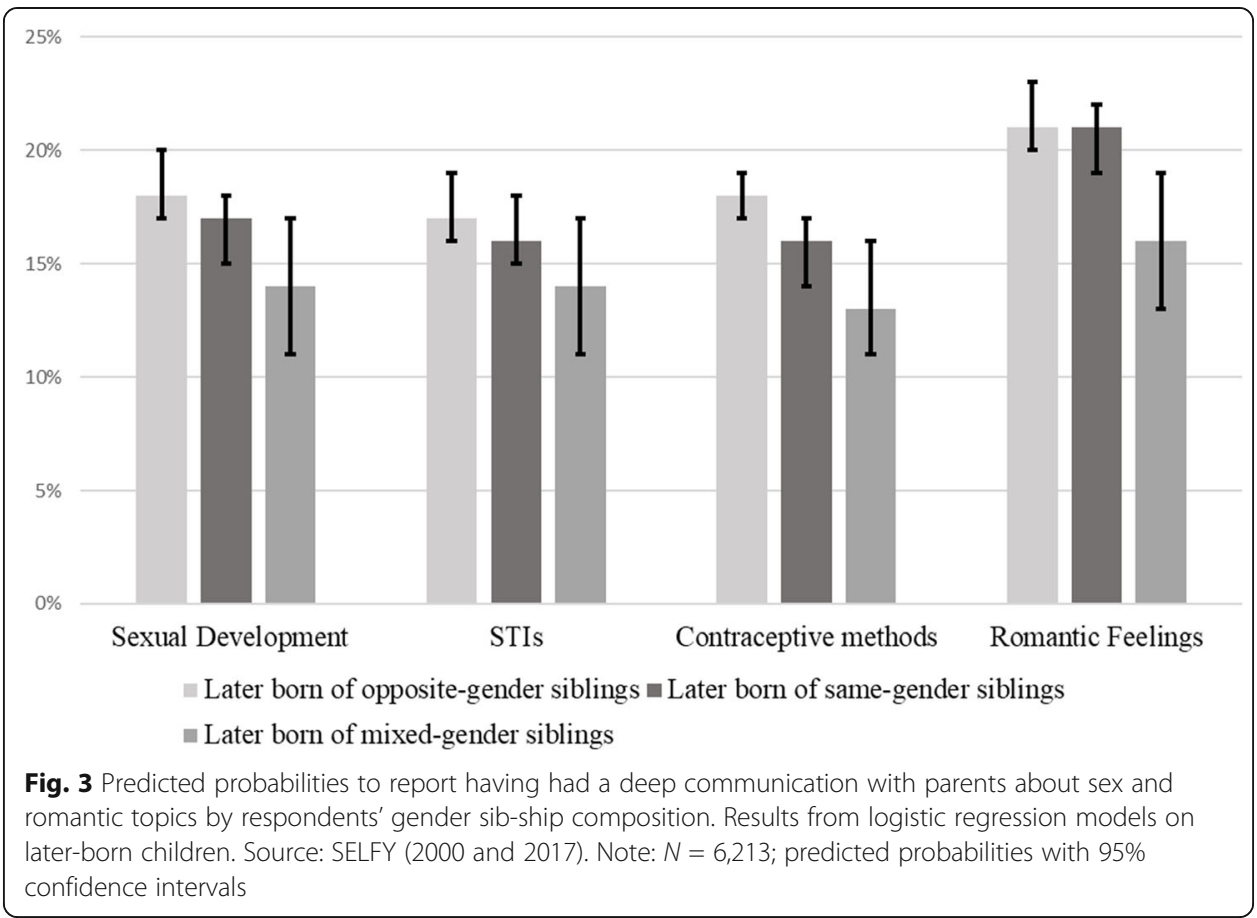

skilled" (unskilled manual worker, lower-grade routine non-manual employee, lower-grade military officer), "medium-skilled" (skilled manual worker, higher-grade routine nonmanual employee, teacher, self-employed with or without employees), or "high-skilled" (entrepreneur, manager, professional with or without employees, higher-grade military officer). The level of communication of parents with adolescent children might be related to time spent with them at home; thus, we controlled for whether the mother was employed when the respondent was 13 years old ("not employed" or "employed"). Since the date of births of each sibling is not available, but only that of the parent's first child, we added a variable accounting for the time spacing between the respondent's birth and that of his/her oldest brother or sister, that is the birthday of the first child born to the student's parents. We assume that the longer this time interval, the greater the distance between parents and the younger children in terms of communication (Ferrari \& Dalla Zuanna, 2010; Merllié \& Monso, 2007). Even the parents' age matters: the capacity of parents to take care of children (Juster, 1985; Walter, 1986), to relate to them (Heuvel, 1988) and to spend time with them (Sayer, Gauthier, \& Furstenberg Jr., 2004) decreases with age. This negative effect could be counterbalanced by the economic advantage to have relatively old parents. In fact, older parents generally have higher economic resources compared with younger ones since socioeconomic situations tend to improve over the life course and this is a potential advantage for children in terms of material resources available (Powell, Steelman, \& Carini, 2006). Thus, we controlled for the mother's and father's age at the time of the respondent's birth. The variable includes four age classes: under 25, 26-30; 31-35; 36-40; over 40. Finally, since birth-order differences in the level of communication with parents between age 14 and 18 may strongly be correlated to the overall quality of the relationship with them, especially in terms of how they react to the restrictions set forth by parents (Malacane \& Beckmeyer, 2016; Wilson, Dalberth, Koo, \& Gard, 2010), we controlled for how students 
reported about their usual way to react to parental rules: 1 = "seeking to negotiate more freedom"; 2 = "accepting without discussing"; 3 = "quarrelling".

As said above, the data came from two successive cross-sectional surveys carried out in 2000 and 2017. We pooled the two surveys and introduced a dummy variable in the model indicating whether the respondent was interviewed in 2000 or in 2017. Thus, we verified whether the level of parent-child communication regarding sexual matters has changed over time as in other countries (Tabak et al., 2012) or whether it is substantially stable as suggested by previous analyses of these same data (Dalla Zuanna et al., 2019).

\section{Results}

Descriptive statistics

Descriptive statistics are reported in Table 1, revealing meaningful differences between the two groups of respondents: first-born/only child $(N=6004)$ versus later-born children $(N=$ 6261). Later-born students, almost half of whom have same-gender siblings, display lower levels of communication with parents about sexual development, STIs, contraceptive methods, and romantic feelings than first-born/only child students $\left(X^{2} p\right.$ value $\left.<0.001\right)$.

Men represent $48.2 \%$ of the sample and the mean age of respondents is about 21 years old. About $96 \%$ of the sample is composed of students born in Italy and $41 \%$ live in the South. The final lower-secondary school grade for later-born students was significantly lower on average than for first-born/only child students, but respondents with older siblings participated in religious groups (when 11-13 years old) and reported to seek to negotiate more freedom from parents' rules more often than the first-born/only children. Only about $6 \%$ of the students enrolled in the study have experienced parental divorce during their childhood and the prevalence is slightly higher among first-born/only children. Most respondents reported having parents with an upper-secondary level of education, but the percentage is significantly lower among students with older siblings. Instead, we observe a slightly higher prevalence of later-born students whose fathers had a highskilled job (32.1\%) compared with first-born/only child students $\left(29.3 \%, X^{2} p\right.$ value < 0.001). ${ }^{1}$ Statistically, significant differences based on birth order have been also found for the mother's employment status, with later-born students more often reporting working mothers $\left(X^{2} p\right.$ value $\left.<0.001\right)$. The proportion of those having parents who were aged $35+$ when they were born is significantly higher among later-born students compared with first-born/only child students $\left(X^{2} p\right.$ value $\left.<0.001\right)$.

\section{The association between birth order and parent-child communication}

Table 2 displays the results from multivariate logistic regression models testing the association between the birth order and the level of communication with parents about, respectively, sexual development (model 1), STIs (model 2), contraceptive methods (model 3), and romantic feelings (model 4). Net of socio-economic and demographic characteristics, the association between birth order and having had deep communication with parents about sexual development, STIs, contraceptive methods, and romantic feelings was statistically significant and negative in sign as expected (HP1).

${ }^{1}$ Since the frequency of "never worked" fathers is very low $(0.88 \%)$, these cases have been dropped out from the following regression analysis although a check has shown that their inclusion did not change the results (available upon request). 
In order to ease the interpretation of results, we computed the predicted probabilities (Fig. 1) for an individual to have had a deep conversation with parents on each specific topic. ${ }^{2}$ Compared with first-born/only child students, being a later-born child reduces the probability of having had a deep communication with parents about sexual development by 4.5 percentage points $(p$ value $<0.01)$; that of talking about STIs by 2.3 percentage points $(p$ value $<0.01)$, and the probability of having had a deep communication with parents about contraceptive methods and romantic feelings by 3.5 and 4.1 percentage points, respectively $(p$ value $<0.01)$.

Parent-child communication is also highly differentiated by gender, with boys significantly less likely than girls to talk with parents about sexual development, contraceptive methods, and romantic feelings. Figure 2 shows the predicted probabilities of a deep communication with parents on different topics based on the respondent's gender. The boys' probability of having had a deep communication with parents about sexual development is about 12 percentage points lower than girls ( $p$ value $<0.01$ ); to have discussed contraceptive methods with parents is about 4 percentage points lower than for girls ( $p$ value $<$ 0.01 ); concerning romantic feelings, the difference in terms of probability between men and women is even higher, with men being about 14 percentage points less likely to turn to parents as confidants during adolescence ( $p$ value $<0.01$ ). Finally, our analyses did not show any statistically significant difference in the probability to have had a deep communication with parents about STIs between men and women ( $p$ value $>0.1$ ).

In order to test the hypothesis that the effect of having older siblings on the level of communication with parents is not the same for girls and for boys (HP2), we included an interaction term between birth order and gender. This term is not statistically significant in any model ( $p$ value $>0.1$ ) showing that gender did not moderate the association between birth order and the outcomes. Thus, our second hypothesis (HP2) is not confirmed.

Table 2 includes the results for the socio-demographic correlates and other control variables included in the logistic regression model, one for each of the topics of conversation considered. Many of the effects are in line with our expectations, while others are quite unexpected and will deserve further studies. Overall, the odds of having had a deep communication with parents about sexual development and romantic feelings decrease with respondent's age is lower if the respondents were resident in the South of Italy and if secondary school performance was low (significantly so only for the models on talking about STIs and contraceptive methods). Having regularly participated at religious groups in the pre-adolescence period was positively associated with having had deep talks with parents later in life about sexual development, STIs, and romantic feelings but not about contraceptive methods, suggesting that students raised within a religious context were more likely to have learned an open way to talk about sexuality with adults. Also, having often talked about sex with friends in the pre-adolescence period (age 11 to 13) was positively associated with confidence with parents in the following years (14 to 18), which is a somewhat unexpected result. Contrary to our expectations, parental union dissolution before the age of 13 was positively associated with a

${ }^{2}$ Figures of predicted probability and their $95 \%$ confidence intervals (CI) have been reported in Appendix Table 4. In Table 5, the average marginal effects (AMEs) are reported. The AME of each covariate represents the percentage points change in the predicted probability of having had a deep communication with parents about sex and romantic feelings for key independent variables, averaged across the values of the other covariates. 
deep communication with parents around each topic considered. The mother's high level of education showed positive and statistically significant effects on deep communication with adolescent children and the same held for the father's high-skilled job, suggesting a positive association between the parents' socio-economic status and their ability to communicate with their children. Parental age was not always significant but when it was, the direction of the effect is the expected one: the older the parent, the lower the odds of talking with their children about sex and romantic feelings. The mother's age seems to count more in this respect. As expected, if the respondent used to quarrel with parents as a reaction to their rules and restrictions when he/she was adolescent, the odds of involving them in discussions about sex and feelings were reduced. This result confirms that the quality of the relationship with parents plays a fundamental role in providing a solid base from which to have a deep communication. Finally, the year-of-survey term was significant whichever topic is considered $(p<0.1$ for sexual development and $p<0.01$ for the other topics), suggesting that parent-child communication about sex and feelings has changed in the last 17 years. However, the sign is varying: the odds of talking with parents about sexual development and sexually transmitted diseases have reduced between the surveys 2000 and 2017, while the odds of talking with parents about contraceptive methods and romantic feelings have increased. We will further discuss these results in the concluding section of this paper.

\section{The role of the sib-ship gender composition}

Focusing on the sub-sample of students who were later-born children, that is, those who declared having older living brothers or sisters at the time of the interview, we explored possible differentials arising from sib-ship gender composition. Results reported in Table $3^{3}$ and Fig. 3 show that compared with later-born opposite-gender siblings, those growing up with older same-gender siblings were less likely to have had a deep talk with parents, but only as for contraceptive methods (significance at 10\% level). On average, the probability of having had a deep communication with parents about contraception among students with same-gender siblings was about 2 percentage points lower $(p$ value $<0.1)$ than among those who are laterborn of only opposite-gender brothers/sisters. Also, students with mixed-gender older siblings showed a significantly lower probability than students who have only opposite-gender siblings to have had a deep communication with parents about sexual development, contraceptive methods, and romantic feelings ( $p$ value $<0.01$ ). Thus, our hypothesis that having at least one older sibling of own gender prevents children from having a deep communication with parents on sexual affairs and romantic feelings (HP3_1) cannot be refused. Even in this case, the respondent's gender does not significantly moderate the role of sib-ship gender composition: the interaction term between these two variables is not statistically significant in any model. Thus, our last hypothesis (HP3_2), namely the stronger effects of having older, same-gender siblings for girls than for boys-the "sister effect"-is not verified.

\section{Discussion}

The first aim of this paper was to explore whether birth order is related to the level of communication with parents about sexual matters and romantic feelings among Italian

${ }^{3}$ The effects of the socio-demographic and other control factors are practically the same as those reported in Table 2 for the whole sample. Thus, in Table 3, we only reported coefficients of interest adjusted for the other covariates. 
university students. Our findings contribute to previous work by identifying later-born students as significantly less likely than first-born/only children to enter into a deep communication with parents about sexual development, STIs, contraceptive methods, and romantic feelings. According to existing evidence from other European countries, these results demonstrate important disparities in family involvement in sex education, probably due to an increasing dilution of parental time and resources as the number of children increases (Elton et al., 2018; Ferrari \& Dalla Zuanna, 2010; Harkonen, 2012; Pasqualini et al., 2019). The number of siblings could even intensify the proven effect that birth order has on parent-child interactions, since parental time must be distributed more widely and because parental supervision and discipline may be harder to achieve with a greater number of children. Unfortunately, we cannot account for the exact number of children born to parents of our respondents.

Overall, our results also confirm that girls are more likely than boys to talk about "certain" matters with parents (Di Iorio et al., 2003). However, the hypothesis of a moderating role of gender in birth-order effect is not confirmed.

As a second aim, we were interested in further exploring birth-order effects by accounting for the sib-ship gender composition. First, we hypothesized that most of the effect found of being a later-born (vs being a first-born/only child) was due to the fact of being a later-born child with same-gender siblings. Our analyses support the hypothesis by showing that later-born children with at least one same-gender sibling were overall less likely to have had a deep communication with parents compared with students who only had opposite gender older siblings. This finding is in line with prior work showing that having an older same-gender sibling increases the likelihood of referring to siblings as a source of information and as a confidant for romantic affairs by, therefore, decreasing the parental involvement in sex education (Killoren \& Roach, 2014).

We also hypothesized that the above effect was moderated by the respondent's gender, that is we expected that the difference between having same-sex siblings and having opposite-sex siblings was more important among girls than boys (Kowal \& Blinn-Pike, 2004). However, this "sister effect" did not emerge in our analysis based on a sample of Italian university students.

Our estimates draw an interesting picture of changes that occurred in young people's communication with parents about sex and romantic feelings over the last 20 years in Italy. Controlling for the other covariates, the probability of turning to parents as a source of information about sexual development and STIs slightly decreased over time, while the probability of having had a deep communication with parents about contraceptives and romantic feelings during adolescence increased. These results should be looked at as a sign of the changing times: in 2000, the survey was carried out in a historical period of great concern for young people's health due to the spread of sexually transmitted diseases, especially HIV. Many campaigns were in place in Italy to encourage young people to avoid risky behaviours and to increase the use of condoms. It is reasonable to think that conversations with parents were also strongly oriented to these issues. Over time, the alarm of public opinion has somewhat subsided, although this less concern is not supported by scientific and epidemiological evidence, that, instead, documents a persistently high incidence of HIV and STIs in the young population (ECDC, 2018). Meanwhile, the intergenerational discourses have shifted to the domain of feelings and contraceptive choices.

Students residing in the South appears less involved with parents in deep communication, especially about sexual development, STIs, and contraceptive methods: even 
controlling for level of education and household socio-economic status, the cultural resistance of southern Italian parents to talk about "certain things" with their children remains (Barbagli \& Kertzer, 1990; Impicciatore \& Dalla Zuanna, 2006). Among parental characteristics, the most astonishing result was that related to divorce: contrary to our expectation, based on a rich sociological literature, parental divorce does not interrupt the dialogue with children on issues of sexuality and romantic feelings, but rather communication on these matters seems to intensify. Although parental divorce is often associated with reduced parental control and low parental mentoring of children's socialization of sexuality, our results suggest that the mechanism by which the parent-child communication changes after parental divorce needs to be further explored. What is really important is the quality of the relationship between parents and children: in fact, we found an important impact of the way young people reacted to the impositions of parents when they were teenagers on the subsequent dialogue on intimate matters.

Contrary to our expectations, we found a positive association between trust with peers and that with parents on sexual matters and romantic feelings. It should be noted that we considered friends during pre-adolescence and not the current ones, so we could not expect a substitution effect but rather an indicator of the respondent's ability to open up and communicate on intimate subjects. In the same direction, we interpreted the result of the positive association between participation in religious groups when 11 to 13 years old and communication with parents. These findings support the evidence that connectedness, that is the emotional attachment and commitment a child makes to social relationships in the family, peer group, school, etc., is a good predictor of healthy sexual behaviour for youth (Markham et al., 2010).

Some specific limitations of this work must be acknowledged. By the study design, the sample is highly selective since it was collected from university students of selected faculties (Economics and Statistics) and thus evidences are non-representative of the entire Italian youth population. Moreover, we were neither able to differentiate between first-born and only child, or between middle children and last-born children, nor control for the gender of the parents involved in the talking. These gaps in the dataset prevented us from controlling for the number of siblings and for which parent the respondent had deeper communication with about sex and romantic feelings.

We must also underline that both the theoretical and empirical research on this topic is rather scarce and not very updated. Furthermore, prior research mostly focused on the Anglo Saxon and American contexts, and no previous study has been conducted so far on Italy.

This study has the merit of adding content to prior research investigating the determinants of parental involvement in sex education by providing empirical evidence on the Italian case. Moreover, using two comparable waves, we were able to contribute to elucidating changes in family involvement about sexual issues over time.

Despite the undoubted limitations of this research, we wish to underline the possible impact of our results for the policy: there is a general consensus on the importance to enhance the quality of parental involvement in sex and romantic relationship education of their children, which could help to properly elaborate family-based interventions aimed at promoting adolescent health and education (Miller \& Whitaker, 2001; WHO, 2015). Our study suggests that an effective assessment of the quality of parent-child communication in these programmes should take into account the non-negligible role played by siblings. 


\section{Appendix}

Table 4 : Predicted Probabilities

\begin{tabular}{|c|c|c|c|c|c|c|c|c|}
\hline \multirow[t]{4}{*}{ Variables } & \multicolumn{2}{|c|}{$\begin{array}{c}\text { (1) } \\
\text { Sexual Development }\end{array}$} & & \multicolumn{2}{|c|}{$\begin{array}{c}\text { (3) } \\
\text { Contraceptive methods }\end{array}$} & \multicolumn{2}{|c|}{$\begin{array}{c}\text { (4) } \\
\text { Romantic Feelings }\end{array}$} \\
\hline & \multicolumn{3}{|c|}{$\begin{array}{r}\text { Sexual Development } \\
\text { Birth order }\end{array}$} & $\begin{array}{l}\text { (2) } \\
\text { STIs }\end{array}$ & & \multicolumn{2}{|c|}{ Romantic Feelings } \\
\hline & Predicted & & Predicted & & Predicted & & Predicted & \\
\hline & Probability & $95 \%$, C.I & Probability & $95 \%$, C.I & Probability & $95 \%$, C.I & Probability & $95 \%$, C.I \\
\hline First born/Ony child & 0.23 & $(0.21-0.24)$ & 0.20 & $(0.19-0.21)$ & 0.21 & $(0.20-0.22)$ & 0.25 & $(0.24-0.26)$ \\
\hline Later born & 0.18 & $(0.17-0.19)$ & 0.18 & $(0.17-0.19)$ & 0.17 & $(0.16-0.19)$ & 0.21 & $(0.19-0.22)$ \\
\hline \multicolumn{9}{|l|}{ Gender } \\
\hline & Predicted & & Predicted & & Predicted & & Predicted & \\
\hline & Probability & $95 \%$, C.I & Probability & $95 \%$, C.I & Probability & $95 \%$, C.I & Probability & $95 \%$, C.I \\
\hline Woman & 0.26 & $(0.25-0.27)$ & 0.20 & $(0.19-0.21)$ & 0.21 & $(0.20-0.22)$ & 0.30 & $(0.28-0.30)$ \\
\hline Man & 0.14 & $(0.13-0.15)$ & 0.18 & $(0.17-0.20)$ & 0.17 & $(0.16-0.18)$ & 0.15 & $(0.14-0.16)$ \\
\hline \multicolumn{9}{|l|}{ Sib-ship Composition } \\
\hline & Predicted & & Predicted & & Predicted & & Predicted & \\
\hline & Probability & $95 \%$, C.I & Probability & $95 \%$, C.I & Probability & $95 \%$, C.I & Probability & $95 \%$, C.I \\
\hline Later born of opposite-gender siblings & 0.18 & $(0.17-0.20)$ & 0.17 & $(0.16-0.19)$ & 0.18 & $(0.17-0.19)$ & 0.21 & $(0.20-0.23)$ \\
\hline Later born of same-gender siblings & 0.17 & $(0.15-0.18)$ & 0.16 & $(0.15-0.18)$ & 0.16 & $(0.14-0.17)$ & 0.21 & $(0.19-0.22)$ \\
\hline Later born of mixed-gender siblings & 0.14 & $(0.11-0.17)$ & 0.14 & $(0.11-0.17)$ & 0.13 & $(0.11-0.16)$ & 0.16 & $(0.13-0.19)$ \\
\hline
\end{tabular}

Source: SELFY (2000 and 2017)

Note: $\mathrm{N}=12,160$ for hypothesis 1 and 3. $\mathrm{N}=6,213$ for hypothesis 3; Predicted probabilities with $95 \%$

Confidence Intervals $(\mathrm{Cl}) .{ }^{*} p<0.1,{ }^{* *} p<0.05,{ }^{* * *} p<0.01$

Table 5 : Fully Adjusted Average Marginal Effects for Predicted Probabilities

\begin{tabular}{|c|c|c|c|c|c|c|c|c|}
\hline Variables & \multicolumn{2}{|c|}{$\begin{array}{c}1) \\
\text { Sexual Development }\end{array}$} & \multicolumn{2}{|c|}{$\begin{array}{l}\text { (2) } \\
\text { STIs }\end{array}$} & \multicolumn{2}{|c|}{$\begin{array}{c}\text { (3) } \\
\text { Contraceptive methods }\end{array}$} & \multicolumn{2}{|c|}{$\begin{array}{c}(4) \\
\text { Romantic Feelings }\end{array}$} \\
\hline \multirow{2}{*}{\multicolumn{9}{|c|}{ Birth order }} \\
\hline & & & & & & & & \\
\hline Later born (ref. First born/Ony child) & $-0.045^{* * *}$ & $(0.009)$ & $-0.023 * * *$ & $(0.009)$ & $-0.034 * * *$ & $(0.009)$ & $-0.041 * * *$ & $(0.009)$ \\
\hline \multicolumn{9}{|l|}{ Gender } \\
\hline & AME & S.E & AME & S.E & AME & S.E & AME & S.E \\
\hline Man (ref. Woman) & $-0.116^{* * *}$ & $(0.008)$ & 0.020 & $(0.008)$ & $-0.038 * * *$ & $(0.008)$ & $-0.142 * * *$ & $(0.008)$ \\
\hline \multicolumn{9}{|l|}{ Sib-ship Composition } \\
\hline & AME & S.E & AME & S.E & AME & S.E & AME & S.E \\
\hline $\begin{array}{l}\text { Later born of same-gender siblings (ref. Later born of opposite- } \\
\text { gender siblings) } \\
\text { Later born of mixed-gender siblings (ref. Later born of }\end{array}$ & -0.009 & $(0.010)$ & -0.008 & $(0.010)$ & $-0.020 *$ & $(0.010)$ & -0.005 & $(0.011)$ \\
\hline opposite-gender siblings) & $-0.039 * *$ & $(0.016)$ & -0.029 & $(0.017)$ & $-0.043 * *$ & $(0.016)$ & $-0.052 * * *$ & $(0.017)$ \\
\hline
\end{tabular}

Source: SELFY (2000 and 2017)

Note: $\mathrm{N}=12,160$ for hypothesis 1 and 3. $\mathrm{N}=6,213$ for hypothesis 3; Average Marginal Effects (AMEs) with standard errors (SE). ${ }^{*} p<0.1,{ }^{* *} p<0.05,{ }^{* * *} p<0.01$ 


\section{Authors' contributions}

MP conceived the study, performed the statistical analysis, and drafted the manuscript for the background, the empirical strategy and the results sections. ADR participated in the research design and drafted the manuscript for the data, methods, discussions, and conclusion sections. All the authors declare that they read and approved the final manuscript.

\section{Funding}

The authors declare that no research funding was used to develop this article.

\section{Availability of data and materials}

The datasets used and/or analysed during the current study are available from the corresponding author on reasonable request.

\section{Competing interests}

The authors declare that they have no competing interests.

\section{Author details}

'Department of Political and Social Sciences, Universitat Pompeu Fabra, C/ Ramon Trias Fargas, 25-27, 08005 Barcelona, Spain. ${ }^{2}$ Department of Methods and Models for Economics, Territory and Finance, Sapienza University of Rome, Roma, Italy.

\section{Received: 16 October 2019 Accepted: 10 August 2020}

Published online: 24 August 2020

\section{References}

Barbagli, M., \& Kertzer, D. I. (1990). An introduction to the history of italian family life. Journal of Family History, 15(4), $369-383$. Baskett, L. M. (1985). Sibling status effects: Adult expectations. Developmental Psychology, $21(3), 441$.

Booth, A. L., \& Kee, H. J. (2009). Birth order matters: The effect of family size and birth order on educational attainment. Journal of Population Economics, 22(1), 367-397.

Bu, F., \& Sulloway, F. J. (2016). Birth order and parental investment. In T. K. Shackelford, \& V. A. Weekes-Shackelford (Eds.), Encyclopedia of evolutionary psychological science, (pp. 1-6). Cham: Springer International Publishing.

Byers, E. S., Sears, H. A., \& Weaver, A. D. (2008). Parents' reports of sexual communication with children in kindergarten to grade 8. Journal of Marriage and Family, 70(1), 86-96. https://doi.org/10.1111/j.1741-3737.2007.00463.x.

Caltabiano, M. (2006). The first romantic relationship of adolescents: A comparative analysis. Genus, 61(2), 141-160.

Caltabiano, M., Dalla Zuanna, G., \& Rosina, A. (2006). Interdependence between sexual debut and church attendance in Italy. Demographic Research, 14(19), 453-484.

Cheshire, E., Kaestle, C. E., \& Miyazaki, Y. (2019). The influence of parent and parent-adolescent relationship characteristics on sexual trajectories into adulthood. Archives of Sexual Behavior, 48(3), 893-910.

Chewning, B., \& Van Koningsveld, R. (1998). Predicting adolescents' initiation of intercourse and contraceptive use. Journal of Applied Social Psychology, 28(14), 1245-1285.

Crosby, R. A., Hanson, A., \& Rager, K. (2009). The protective value of parental sex education: A clinic-based exploratory study of adolescent females. Journal of Pediatric and Adolescent Gynecology, 22(3), 189-192.

Dalla Zuanna, G., Caltabiano, M., Minello, A., \& Vignoli, D. (2019). Catching up! The sexual opinions and behaviour of Italian students (2000-2017). Working Paper No. 2019/02. Firenze: Università degli Studi di Firenze, Dipartimento di Statistica, Informatica, Applicazioni" G. Parenti".

Darling, C. A., \& Hicks, M. W. (1982). Parental influence on adolescent sexuality: Implications for parents as educators. Journal of Youth and Adolescence, 11(3), 231-245.

D'Cruz, J., Santa Maria, D., Dube, S., Markham, C., McLaughlin, J., Wilkerson, J. M., \& Shegog, R. (2015). Promoting parent-child sexual health dialogue with an intergenerational game: Parent and youth perspectives. Games for Health Journal, 4(2), $113-122$.

Di lorio, C., Pluhar, E., \& Belcher, L. (2003). Parent-child communication about sexuality. A review of the literature form 19802002. Journal of HIV/AIDS Prevention \& Education for Adolescents \& Children, 5(3-4), 7-32. https://doi.org/10.1300/ J129v05n03_02.

Dishion, T. J., Piehler, T. F., \& Myers, M. W. (2008). Dynamics and ecology of adolescent peer contagion. In M. J. Prinstein, \& K. A. Dodge (Eds.), Understanding peer influence in children and adolescents, (pp. 72-93). New York, NY: Guilford.

ECDC - European Centre for Disease Prevention and Control (2018). HIV/AIDS surveillance in Europe 2017 data. Retrieved from http://www.euro.who.int/_ data/assets/pdf_file/0004/386959/

Eisenberg, M. E., Sieving, R. E., Bearinger, L. H., Swain, C., \& Resnick, M. D. (2006). Parents' communication with adolescents about sexual behaviour: A missed opportunity for prevention? Journal of Youth and Adolescence, 35(6), 893-902.

Elton, L., Palmer, M., \& Macdowall, W. (2018). Birth order and parental and sibling involvement in sex education. A nationallyrepresentative analysis. Sex education, 19(2), 162-179.

Feldman, S. S., \& Brown, N. L. (1993). Family influences on adolescent male sexuality: The mediational role of self-restraint. Social Development, 2(1), 15-35.

Ferrari, G., \& Dalla Zuanna, G. (2010). Siblings and human capital: A comparison between Italy and France. Demographic Research, 23(21), 587-614.

Furstenberg Jr., F. F., Moore, K. A., \& Peterson, J. L. (1985). Sex education and sexual experience among adolescents. American Journal of Public Health, 75(11), 1331-1332.

Harkonen, J. (2012). Birth order, educational attainment and educational transitions in West Germany. European Sociological Review, 30(2), 166-179.

Hertwig, R., Davis, J. N., \& Sulloway, F. J. (2002). Parental investment: How an equity motive can produce inequality. Psychological Bulletin, 128(5), 728-745. 
Heuvel, A. V. (1988). The timing of parenthood and intergenerational relations. Journal of Marriage and the Family, 50(2), 483491.

Hogan, D. P., \& Kitagawa, E. M. (1985). The impact of social status, family structure, and neighborhood on the fertility of black adolescents. American Journal of Sociology, 90(4), 825-855.

Hotz, V. J., \& Pantano, J. (2015). Strategic parenting, birth order, and school performance. Journal of Population Economics, 28(4), $911-936$

Hutchinson, M. K., Jemmott, J. B., Jemmott, L. S., Braverman, P., \& Fong, G. T. (2003). The role of mother-daughter sexual risk communication in reducing sexual risk behaviors among urban adolescent females: A prospective study. Journal of Adolescent Health, 333(2), 98-107.

Impicciatore, R., \& Dalla Zuanna, G. (2006). A difficult social mobility: The education of children of southern parents emigrated to central and North Italy. Genus, 62(3/4), 155-201.

Juster, F. T. (1985). Investments of Time by men and women. In F. T. Juster, \& F. P. Stafford (Eds.), Time, goods, and well-being, (pp. 177-204). Ann Arbor: University of Michigan, Institute for Social Research.

Killoren, S. E., \& Roach, A. L. (2014). Sibling conversations about dating and sexuality: Sisters as confidants, sources of support, and mentors. Family Relations, 63(2), 232-243. https://doi.org/10.1111/fare.12057.

Kowal, A., \& Blinn-Pike, L. (2004). Sibling influences on adolescents' attitudes toward safe sex practices. Family Relations, 53(4), 377-384. https://doi.org/10.1111/j.0197-6664.2004.00044.x.

Macdowall, W., Jones, K. G., Tanton, C., Clifton, S., Copas, A. J., Mercer, C. H., \& Field, N. (2015). Associations between source of information about sex and sexual health outcomes in Britain: Findings from the third National Survey of sexual attitudes and lifestyles (Natsal-3). BMJ Open, 5(3), e007837.

Macdowall, W., Wellings, K., Mercer, C. H., Nanchahal, K., Copas, A. J., McManus, S., \& Johnson, A. M. (2006). Learning about sex: Results from Natsal 2000. Health Education \& Behavior, 33(6), 802-811.

Malacane, M., \& Beckmeyer, J. J. (2016). A review of parent-based barriers to parent-adolescent communication about sex and sexuality: Implications for sex and family educators. American Journal of sexual Education, 11(1), 27-40. https://doi. org/10.1080/15546128.2016.1146187.

Markham, C. M., Lormand, D., Gloppen, K. M., Peskin, M. F., Flores, B., Low, B., \& Duane House, L. (2010). Connectedness as a predictor of sexual and reproductive health outcomes for youth. Journal of Adolescent Health, 46(3S), S23-S41.

McHale, S. M., Updegraff, K. A., \& Whiteman, S. D. (2012). Sibling relationships and influences in childhood and adolescence. Journal of Marriage and Family, 74(5), 913-930.

McLanahan, S., \& Bumpass, L. (1988). Intergenerational consequences of marital disruption. American Journal of Sociology, 94(1), 130-152.

Merllié, D., \& Monso, O. (2007). La destinée sociale varie avec le nombre de frères et soeurs, INSEE, France, portrait social (pp.135153). Paris: INSEE.

Miller, B. C. (1998). Families matter: A research synthesis of family influences on adolescent pregnancy. Washington, DC: National Campaign to Prevent Teen Pregnancy.

Miller, K. S., \& Whitaker, D. J. (2001). Predictors of mother-adolescent discussions about condoms: Implications for providers who serve youth. Pediatrics, 108(2), 1-7.

Moore, K. A., Peterson, J. L., \& Furstenberg, F. F. (1986). Parental attitudes and the occurrence of early sexual activity. Journal of Marriage and the Family, 48(4), 777-782.

Morris, A. S., Silk, J. S., Steinberg, L., Myers, S. S., \& Robinson, L. R. (2007). The role of the family context in the development of emotion regulation. Social Development, 16(2), 361-388. https://doi.org/https://doi.org/10.1111/j.1467-9507.2007.00389.x.

Ng, W. L., Mofrad, S., \& Uba, I. (2014). Effect of birth order on the differential parental treatment of children. Asian Social Science, 10(14), 132-137.

Nolin, M., \& Peterson, K. (1992). Gender differences in parent-child communication about sexuality: An exploratory study. Journal of Adolescent Research, 7(1), 59-79. https://doi.org/10.1177/074355489271005.

Olusanya, O. O. (2018). The role of household power relation on parent-child communication and adolescent sexual health in Ondo state, Nigeria. Journal of Emerging Trends in Economics and Management Sciences, 9(5), 263-269.

Pasqualini, M., Sacker, A., McMunn, A. (2019). Birth order and first sexual experience: do siblings influence adolescents sexual debut? In Pasqualini M. Family Matters in Influencing Health Risk Behaviours: A Life Course Perspective. PhD Thesis. Department of Statistics, Roma: Sapienza University of Rome.

Potard, C., Courtois, R., \& Rusch, E. (2008). The influence of peers on risky sexual behaviour during adolescence. The European Journal of Contraception \& Reproductive Health Care, 13(3), 264-270. https://doi.org/10.1080/13625180802273530.

Powell, B., Steelman, L.C., \& Carini, R.M. (2006). Advancing age, advantaged youth: Parental age and the transmission of resources to children. Social Forces, 84(3), 1359-1390. https://doi.org/https://doi.org/10.1353/sof.2006.0064.

Racz, S., \& McMahon, R. (2011). The relationship between parental knowledge and monitoring and child and adolescent conduct problems: A 10-year update. Clinical Child and Family Psychology Review, 14(4), 377-398. https://doi.org/10.1007/ s10567-011-0099-y.

Regnerus, M. D. (2005). Talking about sex: Religion and patterns of parent-child communication about sex and contraception. The Sociological Quarterly, 46(1), 79-105.

Rodgers, J. L., \& Rowe, D. C. (1988). Influence of siblings on adolescent sexual behavior. Developmental Psychology, 24, 722728. https://doi.org/10.1037/0012-1649.24.5.722.

Rodgers, J. L., Rowe, D. C., \& Harris, D. F. (1992). Sibling differences in adolescent sexual behavior: Inferring process models from family composition patterns. Journal of Marriage and the Family, 54(1), 142-152.

Rogers, A. A., Ha, T., Stormshak, E. A., \& Dishion, T. J. (2015). Quality of parent-adolescent conversations about sex and adolescent sexual behavior: An observational study. Journal of Adolescent Health, 57(2), 174-178.

Sayer, L. C., Gauthier, A. H., \& Furstenberg Jr., F. F. (2004). Educational differences in parents' time with children: Cross-national variations. Journal of Marriage and Family, 66(5), 1152-1169.

Small, S. A., \& Luster, T. (1994). Adolescent sexual activity: An ecological, risk-factor approach. Journal of Marriage and the Family, 56(1), 181-192.

Sulloway, F. J. (1996). Born to rebel: Birth order, family dynamics, and creative lives. New York: Pantheon Books. 
Sulloway, F. J. (2007). Birth order and sibling competition. In R. Dunbar, \& L. Barrett (Eds.), The Oxford handbook of evolutionary psychology, (pp. 297-311). Oxford: Oxford University Press.

Tabak, I., Mazur, J., del Carmen Granado Alcón, M., Örkenyi, A., Zaborskis, A., Aasvee, K., \& Moreno, C. (2012). Examining trends in parent-child communication in europe over 12 years. The Journal of Early Adolescence, 32(1), 26-54. https://doi.org/ https://doi.org/10.1177/0272431611419509

Walter, C. A. (1986). The timing of motherhood. Lexington MA: Heath.

Whalen, C., Henker, B., Hollingshead, J., \& Burgess, S. (1996). Parent-adolescent dialogues about AIDS. Journal of Family Psychology, 10(3), 343-357.

WHO (2015). Adolescent health research priorities: Report of a technical consultation. Geneva: World Health Organization https:// apps.who.int/iris/handle/10665/203564.

Widman, L., Choukas-Bradley, S., Noar, S. M., Nesi, J., \& Garrett, K. (2016). Parent-adolescent sexual communication and adolescent safer sex behavior: A meta-analysis. JAMA Pediatrics, 170(1), 52-61.

Widmer, E. D. (1997). Influence of older siblings on initiation of sexual intercourse. Journal of Marriage and the Family, 59(4), 928-938.

Wilson, E. K., Dalberth, B. T., Koo, H. P., \& Gard, J. C. (2010). Parents' perspectives on talking to preteenage children about sex. Perspectives on Sexual and Reproductive Health, 42(1), 56-63.

Wilson, E.K., \& Koo, H.P. (2010). Mothers, fathers, sons, and daughters: Gender differences in factors associated with parentchild communication about sexual topics. Reproductive Health, 7(31), 1-9. https://doi.org/https://doi.org/10.1186/17424755-7-31

\section{Publisher's Note}

Springer Nature remains neutral with regard to jurisdictional claims in published maps and institutional affiliations.

Submit your manuscript to a SpringerOpen ${ }^{\odot}$ journal and benefit from:

- Convenient online submission

- Rigorous peer review

- Open access: articles freely available online

- High visibility within the field

- Retaining the copyright to your article

Submit your next manuscript at $\boldsymbol{\nabla}$ springeropen.com 